\title{
Evaluasi Tepung Daun Kelor (Moringa oleifera) yang dihidrolisis Cairan Rumen Domba sebagai Bahan Baku Pakan Ikan Lele (Clarias sp.) \\ Evaluation of Moringa Leaves (Moringa oleifera) Meal Hydrolyzed by Sheep Rumen Liquor as Feed Ingredient For Catfish Feed (Clarias sp.)
}

\author{
Achmad Noerkhaerin Putra*, Irhas Malik Maula, Aryati Aryati, Mas Bayu Syamsunarno \& Mustahal Mustahal \\ Department of Fisheries, University of Sultan Ageng Tirtayasa, Serang, Banten, Indonesia \\ ${ }^{*}$ Corresponding author, email: putra.achmadnp@untirta.ac.id
}

Submitted 01 July 2020 Revised 09 August 2020 Accepted 30 November 2020

\begin{abstract}
ABSTRAK Serat kasar tinggi yang terkandung dalam tepung daun kelor (TDK) menjadi penghambat penggunaan TDK sebagai bahan baku pakan ikan lele. Penelitian ini bertujuan untuk mengevaluasi penggunaan TDK yang dihidrolisis dengan cairan rumen domba untuk pakan ikan lele. Uji hidrolisis pada TDK dengan menggunakan 4 dosis cairan rumen yaitu $0,100,125,175 \mathrm{~mL} / \mathrm{kg}$ dan lama inkubasi selama $0,12,24$ jam, dilakukan untuk memperoleh dosis dan waktu inkubasi terbaik untuk menurunkan nilai serat kasar dalam TDK. Penelitian terdiri dari tiga pelakuan dan tiga kali ulangan, yaitu pakan referensi/acuan, pakan uji TDK tanpa hidrolis cairan rumen, dan pakan uji TDK dengan hidrolisis cairan rumen. Ikan lele dengan bobot sebesar 5,05 $\pm 0,005 \mathrm{~g}$ dipelihara selama 45 hari dengan padat tebar 15 ekor/wadah. Hasil penelitian menunjukkan bahwa dosis rumen $175 \mathrm{~mL} /$ $\mathrm{kg}$ dengan lama inkubasi 12 jam menghasilkan nilai serat kasar terkecil (4,33\%). Pakan uji TDK dengan hidrolisis cairan rumen menghasilkan nilai kecernaan bahan baku tiga kali lipat lebih besar $(50,19 \%)$ dibandingkan dengan pakan uji tanpa hidrolisis (16,90\%). TDK yang dihidrolisis cairan rumen domba dapat digunakan sebagai bahan baku pakan ikan lele karena meningkatkan kecernaan nutrien, rasio konversi pakan dan pertumbuhan yang lebih tinggi dibandingkan dengan pakan uji TDK tanpa hidrolisis pada pemeliharaan ikan lele.
\end{abstract}

Kata kunci: Cairan rumen domba; hidrolisis enzim; ikan lele; tepung daun kelor

ABSTRACT The high fiber content of moringa leaves meal (MLM) is one of the limiting factors associated with its use in the manufacture of catfish feed. This study aims to evaluate the hydrolysis of moringa leaves meal as the feed ingredient of catfish, using sheep rumen liquor. Hydrolysis test on MLM with the different doses of sheep rumen liquor at $0,100,125$, and $175 \mathrm{~mL} / \mathrm{kg}$ as well as incubation time of 0,12 , and 24 hours, were used to obtain the best doses used in reducing the crude fiber content of the leaves. The control/reference, hydrolyzed, and unhydrolyzed feed tests were used to carry out this research. Furthermore, catfish with an initial weight of $5.05 \pm 0.005 \mathrm{~g}$ were reared for 45 days with a density of 15 fishes per tank. The result showed that the sheep rumen liquor of $175 \mathrm{~mL} / \mathrm{kg}$ and time incubation of 12 hours produces the smallest percentage of crude fiber $(4.33 \%)$. In addition, apparent digestibility and coefficient of feed with hydrolyzed MLM was three times higher $(50.19 \%)$ than unhydrolyzed $(16.90 \%)$. Therefore, the hydrolyzed MLM can be used as raw material for catfish feed because it produces higher nutrient digestibility, feed conversion, and growth compared to the unhydrolyzed.

Keywords: Sheep rumen liquor; enzyme hydrolysis; catfish; moringa leaves meal

\section{PENDAHULUAN}

Ikan lele merupakan ikan ekonomis tinggi dan dibudidayakan secara luas di Indonesia. KKP (2020) menyebutkan bahwa produksi ikan lele di Indonesia pada tahun 2017 menempati urutan ketiga terbesar setelah udang dan ikan nila dengan total produksi sebesar 19.604.260 ton. Peningkatan produksi pada budidaya ikan lele membutuhkan pakan dengan kualitas dan kuantitas yang baik. Pakan akan menghabiskan sekitar 50-60\% dari total biaya produksi pada budidaya ikan intensif, sehingga penghematan dalam jumlah yang sedikit saja akan mempengaruhi keuntungan yang diperoleh para pembudidaya ikan (Nates, 2016). Bahan baku pakan ikan sebagai sumber protein seperti tepung ikan harganya semakin mahal dan ketersedianya semakin terbatas di alam (FAO, 2016). Oleh karena itu, dibutuhkan bahan baku pakan lain untuk mengurangi penggunaan tepung ikan sebagai bahan baku pakan.
Sumber protein nabati telah banyak dipilih menggantikan tepung ikan karena memiiliki kandungan protein yang tinggi dan ketersedian yang melimpah di alam (Hertramp \& Piedad-Pascual, 2000). Penelitian terkait penggantian sebagian atau total dari kandungan tepung ikan dengan sumber protein nabati telah diinvestigasi oleh para peneliti dan memberikan efek positif pada pertumbuhan ikan. Diantaranya adalah penggunaan tepung kedelai (Novriadi, 2017; Zhang et al., 2018; Huang et al., 2017), corn gluten meal (Gerile \& Pirhonen, 2017, Nandakumar et al., 2017), canola meal (Slawski et al. 2013), protein sayuran (Tan et al., 2018) tepung bunga matahari (Ogello et al., 2017), dan tepung lupin kernel (Weiss et al., 2020), dedak dan tepung kacang (Ahmed et al., 2019), tepung daun lamtoro (Putra et al. 2019a) serta limbah sayuran (Putra et al., 2019b). TDK adalah sumber protein nabati yang memiliki potensi digunakan sebagai bahan baku pakan. 
Tanaman kelor (Moringa oleifera) umumnya dimanfaatkan sebagai tanaman pagar, memiliki pertumbuhan yang cepat dan belum termanfaatkan dengan baik di masyarakat. Menurut Shahzad et al. (2018), TDK memiliki kandungan protein yang tinggi, yaitu sebesar 32,22\% dan ketersediaan tanaman kelor melimpah di daerah tropis, termasuk di Indonesia (Putra et al., 2018). Namun, permasalahan penggunaan TDK sebagai bahan baku pakan ikan adalah kandungan serat kasar yang tinggi sebesar 19\% (Mandalla et al., 2013) dan zat antinutrisi yang terdiri dari polyphenols sebesar 4,3\%; tannins sebesar 1,21\%; phytate sebesar 2,54\% dan saponin sebesar 7,93\% (Samkelisiwe \& Ngonidzashe, 2014). NRC (2011) menyatakan bahwa kandungan serat kasar dalam pakan ikan jenis catfish adalah tidak lebih dari 7\%. Pamungkas (2012) juga menambahkan bahwa kandungan serat kasar pada pakan ikan kelompok catfish berkisar antara 3-6\%.

Hidrolisis dengan menggunakan cairan rumen domba adalah salah satu upaya yang dapat dilakukan untuk mendegradasi kandungan serat kasar pada bahan baku pakan. Hidrolisis merupakan proses degradasi serat termasuk selulosa di dalam suatu bahan menjadi gula yang sederhana dengan bantuan katalis enzim (Setyoko \& Utami, 2016). Hidrolisis suatu bahan oleh enzim sangat dipengaruhi oleh kuantitas (dosis) dan lama inkubasi dari proses hidrolisis tersebut (Kamra, 2005). Cairan rumen domba adalah sumber enzim yang murah dan kaya akan enzim-enzim pencerna serat seperti a-amilase, galaktosidase, hemisellulase, sellulase dan xilanase (Williams \& Withers, 1992). Cairan rumen domba memiliki aktivitas enzim selulase sebesar 367,7 IU mL-1 menit-1 dan hemi selulase sebesar 528,6 $\mathrm{IU} \mathrm{mL}^{-1}$ (Zuraida et al., 2012). Pamungkas et al. (2011) menambahkan bahwa cairan rumen domba memiliki aktivitas enzim protease sebesar 0,11 IU mL-1 menit-1, lipase sebesar 0,03 IU mL-1 menit ${ }^{-1}$, amilase sebesar $0,14 \mathrm{IU} \mathrm{mL}^{-1}$ menit $^{-1}$ dan selulase sebesar 0,31 $\mathrm{IU} \mathrm{mL}^{-1}$ menit $^{-1}$. Keberadaan enzim-enzim tersebut menyebabkan domba lebih baik dalam mencerna makananya dibandingkan dengan hewan monogastrik (Kurniasih et al., 2012). Aplikasi hidrolisis cairan rumen domba telah dilaporkan mampu menurunkan kandungan serat kasar dalam bahan baku pakan ikan (Jusadi et al., 2013; Suprayudi et al., 2014; Yusuf et al., 2016; Suprayudi et al., 2017; Pangentasari et al., 2018). Namun, belum ada yang melaporkan penggunan cairan rumen domba pada TDK. Oleh karena itu, tujuan dari penelitian ini adalah untuk mengevaluasi penggunaan TDK yang dihidrolisis dengan cairan rumen domba sebagai bahan baku pakan ikan lele.

\section{BAHAN DAN METODE}

Persiapan hidrolisis cairan rumen

Cairan rumen domba didapatkan dari Rumah Potong Hewan Trondol,A Kabupaten Serang, Provinsi Banten. Metode persiapan cairan rumen domba mengacu pada metode yang digunakan oleh Budiansyah et al. (2010). Cairan rumen sebanyak $1 \mathrm{~L}$ diambil dari domba yang baru saja dipotong kemudian dipindahkan dalam coolbox dan dibawa pada kondisi suhu rendah yaitu $4^{\circ} \mathrm{C}$ untuk menjaga kualitas dari enzim yang akan digunakan. Selanjutnya, cairan rumen yang diperoleh disentrifugasi (HITACHI himac CT6E/CT6EL) selama 20 menit pada suhu $4{ }^{\circ} \mathrm{C}$ dengan kecepatan 10.000 rpm. Supernatan selanjutnya dilarutkan menggunakan ammonium sulfat $60 \%$ (Merck) dan diaduk selama 1 jam menggunakan magnetic stirrer dan disimpan pada suhu $4^{\circ} \mathrm{C}$ selama 24 jam. Supernatan disentrifugasi untuk kedua kalinya pada suhu $4^{\circ} \mathrm{C}$ dan kecepatan 1000 rpm. Supernatan kemudian dibuang dan endapan yang terbentuk selanjutnya dilarutkan menggunakan buffer fosfat $\mathrm{pH} 7,0$ (1:1) dan disimpan pada suhu $4^{\circ} \mathrm{C}$ selama 24 jam sebelum cairan enzim tersebut digunakan.

\section{Uji hidrolisis cairan rumen pada TDK}

Tahap ini menggunakan rancangan acak faktorial yang terdiri dari 2 faktor yang terdiri dari faktor dosis rumen (4 taraf: 0, 100, 125, dan $175 \mathrm{~mL} / \mathrm{kg}$ ) dan faktor lama hidrolisis (3 taraf: 0, 12, dan 24 jam) dan menggunakan tiga kali ulangan. Sebanyak 1 kg TDK disterilisasi terlebih dahulu dengan cara dikukus selama 30 menit. Selanjutnya, cairan rumen ditambahkan pada TDK sesuai dengan perlakuan dan diaduk hingga merata. TDK yang telah dihidrolisis disimpan dalam plastik, kemudian ditutup rapat untuk menghindari kontaminasi dan diinkubasi pada suhu ruang sesuai dengan lama perlakuan. TDK hasil hidrolisis selanjutnya dioven pada suhu $60^{\circ} \mathrm{C}$ dan dianalisis kandungan serat kasarnya berdasarkan metode yang dijelaskan oleh AOAC (1995). Hasil terbaik pada tahapan ini digunakan pada tahapan penelitian berikutnya.

\section{Pembuatan pakan}

Tabel 1. Formulasi dan hasil analisis proksimat pakan penelitian.

\begin{tabular}{|c|c|c|c|}
\hline \multirow{2}{*}{$\begin{array}{l}\text { Komposisi } \\
\text { Pakan }\end{array}$} & \multicolumn{3}{|l|}{ Pakan uji (\%) } \\
\hline & $\begin{array}{l}\text { Pakan } \\
\text { referensi }\end{array}$ & $\begin{array}{l}\text { Pakan tanpa } \\
\text { hidrolisis }\end{array}$ & $\begin{array}{l}\text { Pakan } \\
\text { dengan } \\
\text { hidrolisis }\end{array}$ \\
\hline $\begin{array}{l}\text { Pakan komersil } \\
\text { TDK tanpa } \\
\text { hidrolisis } \\
\text { TDK dengan } \\
\text { hidrolisis } \\
\text { Dedak } \\
\mathrm{Cr}_{2} \mathrm{O}_{3}\end{array}$ & $\begin{array}{l}96,5 \\
- \\
- \\
3,0 \\
0,5\end{array}$ & $\begin{array}{l}66,5 \\
30,0 \\
- \\
3,0 \\
0,5\end{array}$ & $\begin{array}{l}66,5 \\
- \\
30,0 \\
3,0 \\
0,5\end{array}$ \\
\hline Total & 100,0 & 100,0 & 100,0 \\
\hline Analisis proksimat & & & \\
\hline Protein kasar (\%) & $31,33 \pm 0,83$ & $30,39 \pm 0,32$ & $32,04 \pm 0,83$ \\
\hline Lemak kasar (\%) & $5,83 \pm 0,03$ & $5,39 \pm 0,02$ & $6,29 \pm 0,11$ \\
\hline Serat kasar (\%) & $5,55 \pm 0,07$ & $8,72 \pm 0,06$ & $6,80 \pm 0,14$ \\
\hline $\operatorname{BETN}(\%)^{*}$ & $31,11 \pm 0,14$ & $35,51 \pm 0,13$ & $31,42 \pm 0,26$ \\
\hline Kadar air (\%) & $12,22 \pm 0,03$ & $12,41 \pm 0,13$ & $12,46 \pm 0,06$ \\
\hline $\begin{array}{l}\text { Energi }(\mathrm{kkal} / \mathrm{kg} \\
\text { pakan)** }\end{array}$ & $235,12 \pm 3,48$ & $238,74 \pm 0,62$ & $241,57 \pm 2,6 c$ \\
\hline
\end{tabular}

*bahan ekstrak tanpa nitrogen dihitung dengan rumus: 100\%-(kadar protein + lemak + serat + abu + air + abu.

** digestible energy mengacu pada NRC (1993) dengan konversi lemak sebesar 8,1 Kkal/ $\mathrm{kg}$; protein sebesar 3,5 Kkal/kg, dan karbohidrat sebesar 2,5 Kkal/kg.

Bahan yang digunakan adalah TDK tanpa hidrolis cairan rumen dan TDK yang dihidrolis dengan dosis cairan rumen dan lama hidrolisis terbaik hasil dari tahapan penelitian sebelumnya. Pakan uji terdiri dari pakan referensi (70\%) dan bahan uji (30\%) mengacu pada prosedur pengujian bahan baku pakan yang dikemukakan oleh Takeuchi (1988). Pakan referensi yang digunakan adalah pakan komersial ikan lele dengan kandungan protein 30-32\%, lemak 3-5\%, serat 4-6\%, kadar abu 10-13\%, dan kadar air 11-13\%. Pakan 
komersial dibuat tepung dan dihomogenkan dengan bahan baku pakan yang lainnya. Indikator kecernaan menggunakan cromium oxide ( $\mathrm{Cr} 2 \mathrm{O} 3$ ) sebesar $0,5 \%$ (NRC, 1993) dan untuk binder menggunakan dedak sebanyak $5 \%$. Komposisi penyusunan pakan uji pada pemeliharaan ikan lele ditampilkan pada Tabel 1. Tahap ini menggunakan rancangan acak lengkap dengan tiga perlakuan dan tiga kali ulangan, yaitu pakan referensi/acuan, pakan uji TDK tanpa hidrolis dan pakan uji TDK dengan hidrolisis cairan rumen.

\section{Pemeliharaan ikan}

Pemeliharaan ikan dilaksanakan di Laboratorium Budidaya Perikanan, Fakultas Pertanian, Universitas Sultan Ageng Tirtayasa selama 45 hari. Ikan uji yang digunakan adalah ikan lele dengan bobot rata-rata 5,05 $\pm 0,005$ g yang diperoleh dari Tri Farm, Anyer, Kabupaten Serang Provinsi Banten. Ikan dipelihara pada wadah berbentuk bundar dengan diameter $45 \mathrm{~cm}$ dan tinggi $71 \mathrm{~cm}$ dengan kepadatan 15 ekor/wadah. Pemeliharaan menggunakan sistem resirkulasi dengan masing-masing wadah menggunakan 1 aerasi dan 1 bak filter dengan volume 100 L. Ikan dipuasakan terlebih dahulu selama 24 jam untuk menghindari sisa pakan dan aklimatisasi terhadap lingkungan dilakukan selama 5 hari. Pakan uji diberikan setelah proses aklimatisasi selesai dengan frekuensi 3 kali/hari menggunakan metode at satiation atau sekenyangnya. Pengumpulan feses ikan dimulai pada hari ke-7 setelah pemberian pakan uji. Feses dikumpulkan dengan cara disiphon pada dasar wadah pemeliharaan dan disimpan pada suhu $-4^{\circ} \mathrm{C}$ sampai analisis kimia dilakukan. Penyiponan sisa pakan dilakukan setelah pemberian pakan dan sebanyak 30\% dari total volume air diganti setiap 7 hari untuk menjaga kulitas air. Pengukuran suhu dilakukan menggunakan termometer (Hisamatsu) setiap hari pada pagi dan sore hari sedangkan pengukuran kandungan oksigen/dissolved oxygen (DO) menggunakan DO meter (Luxtron DO550) dan pH menggunakan pH meter (luxtron 208) dilakukan setiap 7 hari selama pemeliharaan.

\section{Parameter penelitian}

Nilai jumlah konsumsi pakan, laju pertumbuhan spesifik, rasio konversi pakan dan tingkat kelangsungan hidup pada penelitian ini dihitung melalui persamaan yang dijelaskan oleh Huisman (1987), yaitu:

\footnotetext{
Jumlah konsumsi pakan (g/ikan) = jumlah pakan akhir -jumlah pakan awal

Laju pertumbuhan spesifik (\%/hari) =

(In biomassa ikan akhir-In biomassa ikan awal)/waktu) x 100

Rasio konversi pakan

(jumlah konsumsi pakan)/((biomassa ikan akhir+biomassa ikan mati-biomassa ikan awal)

Tingkat kelangsungan hiduop (\%) =
}

(jumlah ikan pada akhir pemeliharaan)/(jumlah ikan pada awal pemeliharaan) x 100 Nilai kecernaan bahan kering dan kecernaan nutrien yang terdiri dari kecernaan energi, protein dan lemak ditentukan berdasarkan rumus yang dikemukakan oleh Takeuchi (1988). Kecernaan bahan uji/bahan baku digunakan untuk mengetahui besarnya persentasi suatu bahan uji (yang dapat dicerna oleh ikan (Jusadi et al., 2013). Pada penelitian ini, bahan uji yang digunakan adalah TDK tanpa hidrolisis dan TDK dengan hidrolisis cairan rumen domba. Nilai kecernaan bahan uji dihitung dengan persamaan yang dijelaskan oleh Watanabe (1988).
Kecernaan bahan kering $(\%)=$

$100 \times(1-$ (chromium pada pakan/chromium pada feces) $)$

Kecernaan nutrien $(\%)=$

$100 \times(1-$ (chromium pada pakan/chromium pada feces) $\times$ (nutrien pada feces/ nutrien pada pakan))

Kecernaan bahan uji $(\%)=$

(nilai kecernaan pakan uji-0.7 (nilai kecernaan pakan acuan))/0,3

Analisis kimia

Analisis kimia dilakukan di Laboratorium Nutrisi Ikan, Departemen Budidaya Perikanan, IPB-University. Analisis kimia meliputi analisis proksimat yang terdiri dari analisis kadar protein, lemak, serat kasar, abu dan kadar air pada pakan uji dan feces ikan, mengacu pada standar metode dari AOAC (1995). Kadar protein dianalisis dengan metode microKjeldhl menggunakan sistem Kjeldhl. Kadar abu ditentukan dengan menggunakan muffle furnace pada suhu $600^{\circ} \mathrm{C}$ selama 24 jam. Nilai lemak dihitung menggunakan metode ether ekstraksi menggunakan soxhlet, sedangkan kadar air ditentukan melalui pengeringan dalam oven pada suhu $105^{\circ} \mathrm{C}$ selama $3 \mathrm{jam}$. Analisis serat kasar dilakukan dengan menggunakan hidrolisis asam $\left(\mathrm{H}_{2} \mathrm{SO}_{4}\right)$ dan basa $(\mathrm{NaOH})$ serta pencucian dengan air panas, asam dan alkohol. Kandungan chromium dalam pakan dan feses diukur menggunakan spektrofotometer dengan panjang gelombang $350 \mathrm{~nm}$, sesuai dengan metode yang dijelaskan oleh Takeuchi (1988).

\section{Analisis data}

Data pertumbuhan dan kecernaan dianalisis menggunakan Analysis of Variance (ANOVA) dengan selang kepercayaan 95\%. Jika terdapat perbedaan nyata, data selanjutnya dianalis menggunakan uji lanjut Duncan dengan mengacu pada Duncan (1955) menggunakan statistical package for the social sciences (SPPS, v. 17,0). Nilai kecernaan bahan baku dianalisis menggunakan uji t dengan selang kepercayaan 95\%.

\section{HASIL DAN PEMBAHASAN}

Uji hidrolisis cairan rumen pada TDK

Kandungan serat kasar TDK yang dihidrolisis dengan dosis cairan rumen dan lama hidrolisis berbeda tersaji pada Tabel 2. Hasil penelitian menunjukkan bahwa nilai serat kasar perlakuan dosis 100-175 mL/kg pada 0, 12 dan 24 jam secara nyata $(P<0.05)$ lebih kecill nilainya daripada perlakuan dosis $0 \mathrm{~mL} / \mathrm{kg}$. Tidak terdapat perbedaan nilai serat kasar yang nyata $(P>0.05)$ antara perlakuan dosis rumen 100 dan $125 \mathrm{~mL} / \mathrm{kg}$ untuk setiap waktunya (0-24 jam). Nilai serat kasar terendah $(P<0.05)$ terdapat pada dosis rumen $175 \mathrm{~mL} / \mathrm{kg}$ dengan lama inkubasi 12 jam $(4,33 \pm 0,48 \%)$ dan 24 jam $(4,30 \pm 0,68 \%)$.

Tabel 2. Kadar serat kasar TDK yang dihidrolisis dengan cairan rumen domba berdasarkan dosis rumen dan lama hidrolisis*.

\begin{tabular}{|c|c|c|c|c|}
\hline \multirow{2}{*}{$\begin{array}{l}\text { Lama } \\
\text { hidrolisis } \\
\text { (jam) }\end{array}$} & \multicolumn{4}{|c|}{ Dosis cairan rumen $(\mathrm{mL} / \mathrm{kg})$} \\
\hline & 0 & 100 & 125 & 175 \\
\hline 0 & $10,82 \pm 0,00^{b p}$ & $9,36 \pm 0,36^{a p}$ & $8,66 \pm 0,39^{a p}$ & $8,86 \pm 0,40^{\text {a }}$ \\
\hline 12 & $10,82 \pm 0,00^{c p}$ & $9,36 \pm 0,36^{b p}$ & $7,12 \pm 0,70^{\mathrm{b} p}$ & $4,33 \pm 0,28^{a p}$ \\
\hline 24 & $10,82 \pm 0,00^{c p}$ & $9,31 \pm 0,36^{b p}$ & $7,11 \pm 0,78^{b p}$ & $4,30 \pm 0,39^{a p}$ \\
\hline
\end{tabular}

\section{*Keterangan:}

Nilai rata-rata serat kasar \pm SE yang diikuti huruf superscript yang sama menunjukkan nilai yang tidak berbeda nyata $(P>0,05)$

Rancangan acak faktorial, terdiri dari faktor dosis dan lama hidrolisis cairan rumen. Huruf superscript "a, b, c" dibaca secara horizontal dan huruf superscript " $p$, q" dibaca secara vertikal. 
Pertumbuhan dan nilai kecernaan pakan ikan lele Nilai pertumbuhan dan kecernaan pakan pada pemeliharaan ikan lele tersaji pada Tabel 3, sedangkan nilai kecernaan bahan uji pada penelitian ini tersaji pada Tabel 4. Berdasarkan Tabel 3, perlakuan pakan uji TDK dengan hidrolisis cairan rumen secara nyata $(P<0.05)$ memiliki nilai yang lebih baik untuk parameter bobot akhir rata-rata, biomassa akhir, rasio koversi pakan, laju pertumbuhan spesifik dan kecernaan nutrien (bahan kering, protein, lemak dan energi) dibandingkan dengan pakan uji TDK tanpa hidrolisis cairan rumen. Nilai LPS terbaik secara berbeda $(\mathrm{P}<0.05)$ berada pada perlakuan pakan referensi $(2,89 \pm 0,04 \% /$ hari), kemudian pakan uji TDK dengan hidrolisis cairan rumen $(2,81 \pm 0,01 \% /$ hari $)$ dan nilai terkecil terdapat pada perlakuan pakan uji TDK tanpa hidrolisis $(1,64 \pm 0,35 \% / h a r i)$. Tabel 4 menunjukkan bahwa nilai kecernaan bahan uji tertinggi secara berbeda $(\mathrm{P}<0.05)$ berada pada perlakuan pakan uji TDK hidrolisis $(50,19 \pm 0,91 \%)$ dibandingkan dengan nilai

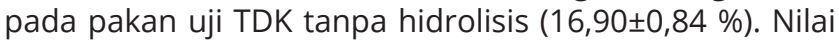
kecernaan bahan kering tertinggi $(P<0,05)$ terdapat pada pakan referensi yaitu sebesar $64,72 \pm 1,64 \%$, kemudian diikuti perlakuan pakan hidrolisis sebesar $57,59 \pm 1,84 \%$ dan nilai kecernaan bahan kering terendah sebesar 50,70 $\pm 0,70 \%$ terdapat pada perlakuan pakan tanpa hidrolisis.

Tabel 3. Nilai pertumbuhan dan kecernaan pakan ikan lele dengan pemberian pakan yang berbeda*.

\begin{tabular}{|c|c|c|c|}
\hline \multirow[b]{2}{*}{ Parameter } & \multicolumn{3}{|l|}{ Pakan uji } \\
\hline & $\begin{array}{l}\text { Pakan } \\
\text { referensi }\end{array}$ & $\begin{array}{l}\text { Pakan tanpa } \\
\text { hidrolisis }\end{array}$ & $\begin{array}{l}\text { Pakan dengan } \\
\text { hidrolisis }\end{array}$ \\
\hline $\begin{array}{l}\text { Bobot awal rata- } \\
\text { rata (g/ikan) }\end{array}$ & $5,04 \pm 0,00$ & $5,05 \pm 0,00$ & $5,05 \pm 0,00$ \\
\hline $\begin{array}{l}\text { Bobot akhir rata- } \\
\text { rata (g/ikan) }\end{array}$ & $13,87 \pm 0,27 c$ & $9,26 \pm 0,27^{a}$ & $11,86 \pm 0,27^{b}$ \\
\hline $\begin{array}{l}\text { Biomassa akhir } \\
\text { (g) }\end{array}$ & $201,00 \pm 4,24 c$ & $134,00 \pm 2,83^{a}$ & $166,00 \pm 2,83^{b}$ \\
\hline $\begin{array}{l}\text { Jumlah konsumsi } \\
\text { pakan (g/ikan) }\end{array}$ & $16,37 \pm 0,70$ & $16,62 \pm 1,36$ & $16,33 \pm 0,96$ \\
\hline $\begin{array}{l}\text { Rasio konversi } \\
\text { pakan }\end{array}$ & $1,43 \pm 0,13^{a}$ & $3,15 \pm 0,29^{b}$ & $1,57 \pm 0,02^{\mathrm{a}}$ \\
\hline $\begin{array}{l}\text { Laju } \\
\text { pertumbuhan } \\
\text { spesifik (\%/hari) }\end{array}$ & $2,89 \pm 0,03^{c}$ & $1,64 \pm 0,25^{a}$ & $2,81 \pm 0,01^{b}$ \\
\hline $\begin{array}{l}\text { Tingkat } \\
\text { Kelangsungan } \\
\text { hidup (\%) }\end{array}$ & $97,78 \pm 2,22$ & $93,33 \pm 6,67$ & $93,33 \pm 3,85$ \\
\hline $\begin{array}{l}\text { Kecernaan bahan } \\
\text { kering (\%) }\end{array}$ & $64,72 \pm 1,16^{c}$ & $50,70 \pm 0,64^{a}$ & $57,59 \pm 1,01^{b}$ \\
\hline $\begin{array}{l}\text { Kecernaan } \\
\text { protein }(\%)\end{array}$ & $81,78 \pm 0,34^{c}$ & $63,26 \pm 0,19^{a}$ & $78,84 \pm 0,14^{b}$ \\
\hline $\begin{array}{l}\text { Kecernaan lemak } \\
(\%)\end{array}$ & $62,14 \pm 1,99^{b}$ & $22,08 \pm 0,15^{a}$ & $61,37 \pm 1,23^{b}$ \\
\hline $\begin{array}{l}\text { Kecernaan energi } \\
(\%)\end{array}$ & $65,14 \pm 0,39 c$ & $50,77 \pm 0,50^{a}$ & $57,59 \pm 1,30^{b}$ \\
\hline
\end{tabular}

*Keterangan: nilai rata-rata \pm SE yang diikuti huruf superscript yang sama pada baris yang sama menunjukkan nilai yang tidak berbeda nyata $(P>0,05)$.

Tabel 4. Nilai kecernaan bahan uji dengan perlakuan TDK yang berbeda*.

\begin{tabular}{ll}
\hline \hline Pakan uji & $\begin{array}{l}\text { Kecernaan } \\
\text { bahan uji (\%) }\end{array}$ \\
\hline Pakan uji TDK tanpa hidrolisis cairan rumen & $16,90 \pm 0,59^{\mathrm{a}}$ \\
Pakan uji TDK dengan hidrolisis cairan rumen & $50,19 \pm 0,64^{\mathrm{b}}$ \\
\hline
\end{tabular}

*Keterangan: nilai rata-rata \pm SE yang diikuti huruf superscript yang sama pada baris yang sama menunjukkan nilai yang tidak berbeda nyata $(P>0,05)$.

\section{Pembahasan}

Serat kasar pada umumnya terdiri dari selulosa, hemi selulosa dan lignin merupakan bahan tidak bernilai dalam nutrisi ikan karnivora (Bonvini et al., 2018). Hansen \& Hamre (2013) menyatakan bahwa bahan baku protein nabati merupakan sumber serat di dalam pakan ikan, yang ketika kandungannya terlalu tinggi akan mengganggu pencernaan pakan pada ikan. Tabel 2 menunjukkan bahwa kandungan serat kasar dalam TDK dengan penambahan cairan rumen (100-175 mL/kg) menurun jumlahnya dibandingkan dengan tanpa penambahan cairan rumen $(0 \mathrm{~mL} / \mathrm{kg})$. Penambahan cairan rumen domba bertujuan untuk menghidrolisis kandungan serat yang terkandung dalam TDK menjadi fraksi yang sederhana. Hidrolisis adalah proses degradasi fiber yang terkandung dalam suatu bahan dengan bantuan katalis enzim (Setyoko \& Utami, 2016). Penurunan nilai serat kasar pada dosis 100$175 \mathrm{ml} / \mathrm{kg}$ menandakan terjadinya proses hidrolisis pada TDK. Hal ini disebabkan cairan rumen domba mengandung enzim pendegrasi serat yang dapat menurunkan nilai serat kasar pada bahan pakan (Pamungkas et al. 2011; Kurniasih et al. 2012). Menurut Murni \& Darmawanti (2016), cairan rumen mengandung enzim amilase dan selulase yang dapat menghidrolis kandungan serat dalam suatu bahan. Argarwal (2003) melaporkan bahwa aktivitas enzim selulase dan hemi selulase yang terkandung dalam cairan rumen domba adalah 367,7 dan 528,6 IU mL $\mathrm{menit}^{-1}$. Pangentasari et al. (2018) juga menambahkan bahwa cairan rumen domba mengandung enzim yang dapat mengurai substrat selulosa sehingga menurunkan kandungan serat kasar. Hasil penelitian juga menunjukkan bahwa tidak ada perbedaan yang nyata $(P<0,05)$ kandungan serat kasar dengan lama hidrolisis 12 dan 24 jam untuk semua dosis cairan rumen. Hal ini mengindikasikan bahwa efektivitas hidrolisis cairan rumen domba dalam menghidrolisis serat yang terkandung pada TDK tidak lebih dari 12 jam. Jusadi et al. (2013) melaporkan hasil yang serupa dimana tidak terjadi perbedaan nilai serat kasar pada kulit buah kakao yang dihidrolisis selama 12 dan 24 jam. Pada penelitian ini, nilai serat kasar terkecil terdapat pada perlakuan dosis rumen $175 \mathrm{~mL} / \mathrm{kg}$ dengan lama hidrolisis selama 12 jam dan 24 jam, dan tidak terdapat perbedaan $(\mathrm{P}<0,05)$ nilai serat kasar pada keduanya, sehingga dosis rumen domba sebesar $175 \mathrm{~mL} / \mathrm{kg}$ dengan lama hidrolisis 12 jam digunakan pada tahapan penelitiaan selanjutnya.

Berdasarkan Tabel 3, jumlah konsumsi pakan yang diperoleh semua perlakuan tidak berbeda $(P>0,05)$. Hasil ini menunjukkan bahwa pemanfaatan TDK sebagai bahan pakan tidak mempengaruhi nafsu makan ikan atau palatabilitas pakan sehingga tidak terdapat perbedaan yang signifikan pada nilai jumlah konsumsi pakan antar semua perlakuan. Hasil serupa diperoleh Mansour et al. (2018), penggunaan daun kelor sebagai bahan baku pakan tidak berdampak pada nilai jumlah konsumsi pakan ikan seabream. Djissou et al. (2020) juga melaporkan hasil yang sama bahwa penggunaan daun kelor sebagai bahan baku pakan tidak mempengaruhi nilai jumlah konsumsi pakan ikan nila.

Nilai konversi pakan menggambarkan banyaknya pakan yang dapat dimanfaatkan atau dikonversi oleh ikan menjadi daging. Makin tinggi nilai konversi pakan maka kualitas pakan tersebut semakin rendah karena dibutuhkan 
pakan dengan jumlah yang tinggi untuk menghasilkan 1 kg daging. Hasil penelitian menunjukkan bahwa pakan uji TDK tanpa hidrolisis cairan rumen menghasilkan nilai konversi pakan yang lebih besar bahkan 2 kali lipat nilainya dibandingkan dengan pakan referensi dan pakan uji TDK dengan hidrolisis. Hal ini menunjukkan ikan lele mengalami kesulitan dalam memanfaatkan pakan uji TDK tanpa hidrolisis. Hasil analisis proksimat pakan (Tabel 1) menunjukkan bahwa kandungan serat kasar pada pakan uji tanpa hidrolisis adalah sebesar $8,72 \%$, pakan uji dengan hidrolisis sebesar 6,8 \% dan pakan referensi sebesar 5,55 $\%$. Kandungan serat kasar yang tinggi pada pakan uji TDK tanpa hidrolisis diduga menyebabkan pakan menjadi sulit dicerna sehingga rasio konversi pakan meningkat. Dugaan ini dikuatkan dengan laporan dari NRC (2011) bahwa kadungan serat kasar pada kelompok ikan catfish tidak lebih dari 7 \%. Altan \& Korkut (2011) juga menyatakan bahwa kandungan serat kasar pada pakan ikan karnivora perlu dibatasi dan tidak lebih dari $7 \%$.

Pertumbuhan adalah energi bersih yang dapat disimpan oleh ikan setelah proses fisiologis dalam tubuh terpenuhi dan nilainya tergantung dari kondisi lingkungan dan asupan nutrisi yang tepat (NRC, 1993). Nilai bobot ratarata akhir, biomassa akhir dan laju pertumbuhan spesifik terbaik terdapat pada perlakuan pakan referensi kemudian diikuti oleh pakan uji TDK hidrolisis cairan rumen dan nilai terkecil terdapat pada pakan uji TDK tanpa hidrolisis. Pertumbuhan yang kecil pada perlakuan pakan uji TDK tanpa hidrolisis diduga terkait dengan nilai kecernaan nutrien yang diperoleh pada perlakuan ini. Semakin tinggi nilai kecernaan nutrien maka nutrien yang dapat diserap oleh tubuh ikan semakin tinggi sehingga pertumbuhan ikan meningkat. Gatlin et al. (2007) mengemukakan bahwa pakan dengan sumber protein nabati memiliki ketersediaan energi yang lebih rendah dibandingkan dengan pakan ikan dengan sumber protein hewani. Hasil penelitian ini sejalan dengan laporan Pangentasari et al. (2018) bahwa pakan uji tanpa penambahan cairan rumen domba menghasilkan pertumbuhan yang lebih rendah dibandingkan pakan dengan penambahan cairan rumen dan pakan referensi. Samkelisiwe \& Ngonidzashe (2014) melaporkan bahwa daun kelor memiliki zat anti nutrisii seperti polyphenols, tannins, phytate, dan saponin. Kami menduga, pakan uji TDK tanpa hidrolisis selain mengandung serat kasar yang tinggi (> $7 \%$ ), juga masih memiliki kandungan zat anti nutrisi yang akan menghambat kecernaan pakan sehingga menghasilkan nilai pertumbuhan yang rendah. Namun, pada penelitian ini kami tidak melakukan analisis terhadap kandungan anti nutrisi pada TDK sebelum dan setelah dihidrolisis.

Hasil penelitian menunjukkan bahwa nilai tingkat kelangsungan hidup atau survival rate ikan yang diperoleh selama pemeliharaan tidak terdapat perbedaan. Hal ini mengindikasikan bahwa dalam penelitian ini, penggunaan daun kelor sebagai bahan baku pakan tidak mempengaruhi proses fisologis pada tubuh ikan lele. Hasil yang sama telah dilaporkan oleh Suprayudi et al. (2011), penambahan enzim cairan rumen pada pakan dengan sumber protein nabati tidak mempengaruhi nilai kelangsungan hidup ikan nila dengan bobot awal pemeliharaan sebesar 6,10 0,49 g. Hal serupa telah dilaporkan oleh Putra et al. (2018), penggunaan daun kelor sebagai bahan baku pakan ikan tidak mempengaruhi nilai tingkat kelangsungan hidup dan gambaran darah (kadar haemoglobin, hematokrit, eritrosit dan leukosit) ikan nila (umur 1 bulan). Hasil yang sama juga ditemukan pada penggunaan pakan berbasis daun tumbuhan yang lainnya, Putra et al. (2019ª) menemukan bahwa penggunaan tepung daun lamtoro sebagai bahan baku pakan tidak berdampak pada nilai tingkat kelangsungan hidup dan gambaran darah ikan lele (umur 1 bulan).

Hasil penelitian menunjukkan bahwa perlakuan pakan uji dengan hidrolisis cairan rumen menghasilkan nilaii kecernaan nutrien (kecernaan bahan kering, protein, lemak dan energi) yang lebih baik $(P<0,05)$ dibandingkan dengan pakan uji TDK tanpa hidrolisis. Hal ini diduga karena peran dari cairan rumen domba dalam menghidrolisis kandungan serat yang terkandung pada TDK sehingga lebih mudah dicerna oleh ikan. Penambahan cairan rumen domba mampu meningkatkan aktivitas enzim selulase, amilase, protease dan lipase pada bahan baku pakan sehingga mampu meningkatkan kecernaan pakan (Fitriliyani et al., 2010; Zuraida et al., 2013). Kamra (2005) menambahkan bahwa enzim-enzim pada cairan rumen terdiri dari hemiselulase untuk menghidrolis hemiselulosa, xilanase untuk menghidrolisis xilosa, amilase untuk menghidrolisis pati, pectinase untuk menghidrolis pectin, lipase untuk mencerna lemak, protease untuk menghidrolisis protein. Hasil serupa telah dilaporkan oleh Pamungkas et al. (2011), hidrolisis cairan rumen domba pada bungkil kelapa sawit secara signifikan $(P<0,05)$ menghasilkan nilai kecernaan bahan kering, protein, lemak dan energi yang lebih baik dibandingkan dengan pakan dengan bungkil kelapa sawit tanpa hidrolisis cairan rumen pada pemeliharaan ikan patin. NRC (1993) menyebutkan bahwa nilai kecernaan protein ikan berkisar 75-95\%, hasil penelitian ini menunjukkan bahwa nilai kecernaan protein pada pakan referensi $(81,78 \%)$ dan pakan uji TDK dengan hidrolisis cairan rumen $(78,84 \%)$ berada pada kisaran normal nilai kecernaan protein ikan. Nilai kecernaan protein yang lebih tinggi pada pakan uji TDK dengan hidrolisis dibandingkan dengan pakan uji TDK tanpa hidrolisis diduga terkait dengan aktivitas enzim protease pada cairan rumen domba. Menurut Pamungkas (2012), cairan rumen domba mengandung enzim protease yang dapat membantu mendegradasi protein di dalam pakan. Zuraida et al. (2013) melaporkan bahwa aktivitas enzim protease dalam cairan rumen domba adalah sebesar 0,057 IU $\mathrm{mL}^{-1}$ menit ${ }^{-1}$. Hasil yang lain dari penelitian ini adalah tidak terjadi perbedaan yang nyata $(P>0,05)$ pada nilai kecernaan lemak antara pakan uji TDK hidrolisis dan pakan referensi. Hal ini mengindikasikan bahwa ikan lele pada perlakuan pakan uji hidrolisis mampu mencerna lemak yang terkandung didalam pakan dengan baik.

Pakan referensi yang digunakan pada penelitian ini adalah pakan komersil untuk ikan lele sehingga menghasilkan nilai kecernaan dan pertumbuhan yang lebih baik dibandingkan dengan perlakuan lainnya. Hasil yang sama diperoleh Jusadi et al. (2013), pakan referensi menghasilkan kecernaan total/bahan kering dan energi yang lebih tinggi dibandingkan dengan pakan tanpa hidrolisis cairan rumen dan pakan dengan hidrolisis cairan rumen pada ikan nila. Pamungkas (2012) juga memperoleh hasil yang sama, perlakuan pakan referensi memiliki kecernaan 
total, kecernaan selulase, kecernaan lignin, kecernaan kalsium dan phosphor yang lebih tinggi pada ikan patin dibandingkan dengan perlakuan pakan uji tanpa hidrolisis dan pakn uji tanpa hidrolisis.

Nilai kecernaan bahan uji atau nilai kecernaan bahan baku adalah nilai yang menunjukkan persentase bahan yang dapat dicerna oleh ikan. Tabel 4 menunjukkan bahwa pakan uji TDK tanpa hidrolisis cairan rumen menghasilkan nilai kecernaan bahan uji sebesar $16,90 \%$ sedangkan pakan uji TDK dengan hidrolisis cairan rumen secara signifikan $(P<0,05)$ menghasilkan nilai kecernaan bahan tiga kali lipat lebih besar yaitu sebesar 50,19 \%. Hasil ini mencerminkan bahwa TDK dengan hidrolisis cairan rumen domba berpotensi sebagai bahan baku pakan ikan lele karena ikan lele mampu mencerna bahan tersebut dengan baik. Hasil yang sama telah dilaporkan oleh para peneliti bahwa penggunaan pakan uji berbasis nabati yang dihidrolisis cairan rumen secara signifikan $(P<0,05)$ menghasilkan kecernaan bahan baku yang lebih tinggi dibandingkan dengan pakan tanpa hidrolisis cairan rumen, diantaranya oleh Pamungkas et al. (2011), melaporkan bahwa kecernaan bahan baku pakan uji dengan hidrolisis cairan rumen domba lebih tinggi sebesar $276 \%$ dari kecernaan bahan baku pakan uji tanpa hidrolisis pada pemeliharaan ikan patin. Jusadi et al. (2013) memperoleh hasil bahwa kecernaan bahan baku pakan uji dengan hidrolisis cairan rumen domba lebih besar sekitar $209 \%$ dari kecernaan bahan baku pakan uji tanpa hidrolisis pada pemeliharaan ikan nila.

Hasil pengukuran nilai kualias air pada penelitian ini menunjukkan bahwa nilai kisaran suhu yang diperoleh adalah sebesar $27-28,2^{\circ} \mathrm{C}$, nilai $\mathrm{pH}$ sebesar 7,0-7,3 dan DO sebesar 6,2-7,3 mg/L. Berdasarkan Bhatnagar \& Devi (2013) nilai kualitas air pada penelitian ini termasuk kedalam kisaran normal dari media pemeliharaan ikan lele.

\section{KESIMPULAN DAN SARAN}

\section{Kesimpulan}

Hidrolisis cairan rumen domba dengan dosis $175 \mathrm{~mL} / \mathrm{kg}$ dan lama inkubasi 12 jam dapat menurunkan kandungan serat kasar pada TDK sampai sebesar 4,33\%. TDK yang dihidrolisis cairan rumen domba dapat digunakan sebagai bahan pakan ikan lele karena menghasilkan kecernaan nutrien dan pertumbuhan yang lebih tinggi dibandingkan dengan pakan uji TDK tanpa hidrolisis.

\section{Saran}

Perlu dilakukan penelitian lanjutan terkait dengan subtitusi TDK yang dihidrolisis cairan rumen domba dalam formulasi pakan ikan lele.

\section{UCAPAN TERIMA KASIH}

Kami mengucapkan terimakasih kepada Rumah Potong Hewan Trondol, Kabupaten Serang, Provinsi Banten atas kesediannya menyediakan cairan rumen domba pada penelitian ini. Kami juga mengucapkan terimakasih kepada Tri Farm, Anyer, Kabupaten Serang Provinsi Banten, karena telah menyediakan benih ikan lele untuk ikan uji pada penelitian ini.

\section{DAFTAR PUSTAKA}

Ahmed, M., H. Liang, H. Kasiya, K. Ji, X. Ge, M. Ren, B. Liu, X. Zhu \& J. Sun. 2019. Complete replacement of fish meal by plant protein ingredients with dietary essential amino acids supplementation for juvenile blunt snout bream (Megalobrama amblycephala). Aquaculture Nutrition 25 (1): 205-214

Altan, O. \& A.Y. Korkut. 2011. Apperent digestibility pf plant protein based diets by European sea bass Dicentrarchus labrax L., 1758. Turkish Journal Fisheries Aquatic Science 11: 87-92

AOAC (Association of Official Analytical Chemists). 1995. Official Methods of Analysis. 16 $6^{\text {th }}$ ed Volume II: Maryland

Argawal. 2003. Role of protein dynamics in reaction rate enhancement by enzymes. American Chemical, 127(43): 48-56

Bhatnagar, A. \& P. Devi. 2013. Water quality guidelines for the management of pond fish culture. International Journal of Environmental Science 3: 1980-2009

Bonvini, E., A. Bonaldo, L. Parma, L. Mandrioli, S. Sirri, M. Grandi, R. Fontanillas, C. Viroli \& P.P. Gatta. 2018. Feeding European sea bass with increasing dietary fibre levels: impact on growth, blood biochemistry, gut histology, gut evacuation. Aquaculture 494: 1-9

Budiansyah, A., Resmib, K.G. Wiryawanc, M.T. Soehartonod, Y. Widyastutie \& N. Ramlic. 2010. Isolasi dan karakterisasi enzim karbohidrase cairan rumen sapi asal rumah potong hewan. Media Peternakan 33 (1): 36-43

Djissou, A.S.M., C.E. Tossavi, I.N. Odjo, S. Khosio \& E.D. Fiogbe. 2020. Use of Moringa oleifera leaves and maggots as protein sources in complete replacement for fish meal I nile tilapia (Oreochromis niloticus) diets. Turkish Journal of Fisheries and Aquatic Sciences 20 (2): $177-183$

Duncan, D.B. 1955. Multiple range and multiple ' $F$ ' tests. Biometrics 11:1-42.

Fitriliyani, I. 2010. Evaluasi nilai nutrisi tepung daun lamtoro gung Leucaena luecophala terhidrolisis dengan ekstrak enzim cairan rumen domba Ovis aries terhadap kinerja pertumbuhan ikan nila Oreochromis niloticus. Jurnal Akuakultur Indonesia 9: 30-37.

Food and Agriculture Organization (FAO). 2016. The state of world fisheries and aquaculture 2016. Contributing to food security and nutrition for all. Rome. 200 pp.

Gatlin, D.M., F.T. Barrows, P. Brown, K. Dabrowski, T.G. Gaylord, R.W. Hardy, W. Herman, G. HU, S. Krogdah, R Nelson, K. Overturf, M. Rust, W. Sealey, D. Skonberg, J. Edward, Souza, D. Stone, R. Wilson \& E. Wurtele. 2007. Expanding the utilization of sustainable plant products in aquafeeds: A review. Aquaculture Research 38: 551-579.

Gerile, S. \& J. Pirhonen. 2017. Replacement of fish meal with corn gluten meal in feeds for juvenile rainbow trout (Oncorhynchus mykiss). Aquaculture 479: 616618. 
Hansen, A.C. \& G.I. Hemre. 2013. Effect of replacing fish meal and oil with plant resources in on-growing diets for Atlantic cod (Gadus morhua L.) Aquaculture Nutrition 19: 641-650.

Hertramp, J.W. \& F. Piedad-Pascual. 2000. Handbook on ingredients for aquaculture feed. Kluwer Academic Publisher. Dordrecht, Netherland. pp. 567.

Huang, F., Wang, L., Zhang, C-X. \& Song, K. 2017. Replacement of fishmeal with soybean meal and mineral supplements in diets of Litopenaeus vannamei reared in low-salinity water. Aquaculture 473: $172-180$.

Huisman, E.A. 1987. Principles of fish production. Department of Fish Culture and Fisheries, Waganingen Agriculture University, Waganingan, Netherland. 170p.

Jusadi, D., J. Ekasari \& A. Kurniansyah. 2013. Peningkatan kualitas kulit buah kakao menggunakan cairan rumen domba untuk pakan ikan nila. Jurnal Akuakultur Indonesia 12 (1): 40-47.

Kamra, D.N. 2005. Special section microbial diversity: rumen microbial ecosystem. Current Science 89 (10):124-135.

Kementrian Kelautan dan Perikanan Republik Indonesia (KKP). 2020. Kelautan dan Perikanan dalam angka. Dikutip dari: https://kkp.go.id/setjen/satudata/ page/1453-kelautan-dan-perikanan-dalam-angka.

Kurniasih, T., I. Fitriliyani, I. Melati \& Z.I. Azwar. 2012. Pemberian ekstrak enzim kasar dari cairan rumen domba pada tepung bungkil kedelai lokal dan pengaruhnya terhadap pertumbuhan ikan nila. Jurnal Riset Akuakultur 7 (2): 247-256.

Mandalla, N., N.W. Agbo \& K. Jauncey. 2013. Evaluation of aqueous extracted moringa Leaf meal as a protein source for nile tilapia juveniles. Tanzania Journal of Agricultural Sciences. 12: 53-64.

Mansour, A.T., L. Miao, C. Espinosa, J.M. Garcia-Beltran, D.C.C. Francisco \& M.A. Esteban. 2018. Effect of dietary inclusion of Moringa oleifera leaves on growth and some systemic and mucosal immune parameters of seabream. Fish Physiology and Biochemistry 44: 1233-1240.

Murni \& Darmawati. 2016. Optimize the use of liquid rumen in fermentation process on increased the nutrients waste vegetables for tilapia's feed. International Journal of Oceans and Oceanography 10: 19-28.

Nandakumar, S., K. Ambasankar, S.S.R. Ali, J. Syamadaya \& K. Vasagam. 2017. Replacement of Fish Meal with Corn Gluten Meal in Feeds for Asian Seabass (Lates calcarifer). Aquaculture International 25 (1): 14951505.

Nates, S.F. 2016. Introduction. In: Nates S., F., editor. Aquafeed Formulation. Academic Press. Oxford, UK. pp xiii-Xxii.

National Research Council (NRC). 1993. Nutrient requirement of fish. National Academic Press. Washington DC, USA. 273 pp.
National Research Council (NRC). 2011. Nutrient requirement of fish and shrimp. National Academy Press, Washington DC, USA. 376 pp.

Novriadi, R. 2017. A meta-analysis approach toward fish meal replacement with fermented soybean meal: effects on fish growth performance and feed conversion ratio. Asian Fisheries Science 30: 227-244.

Ogello, E.O., E.M. Kembenya, C.M. Githukia, C.N. Aera, J.M. Munguti \& C.S. Nyamweya. 2017. Substitution of fish meal with sunflower seed meal in diets for Nile tilapia (Oreochromis niloticus L.) reared in earthen ponds. Journal of Applied Aquaculture 29 (1): 1-19.

Pamungkas, W. 2012. Koefisien kecernaan fraksi serat bungkil kelapa sawit yang dihidrolisis dengan ezim asal cairan rumen domba sebagai pakan benih ikan patin siam (Pangasius hypopyhalmus). Jurnal Riset Akuakultur 7 (3): 437-445.

Pamungkas, W., D. Jusadi \& N.B.P. Utomo. 2011. Uji kecernaan bungkil kelapa sawit yang dihidrolisis dengan enzim cairan rumen domba sebagai pakan benih ikan patin Siam (Pangasius hypopthalmus). Prosiding FITA 2011: 795-800.

Pangentasari, D., M. Setiawati, N.B.P. Utomo \& M.T.D. Sunarno. 2018. Komposisi dan nilai kecernaan nutrient tepung daun tarum (Indigofera zollingeriana) yang difermentasi dengan cairan rumen domba pada benih ikan jelawat (Leptobarbus hoevenii (Bleeker, 1851). Jurnal Akuakultur Indonesia 18 (2): 165-173.

Putra, A.N., Jaenudin, F. Sofia, Mustahal, M. Syamsunarno, D. Hermawan \& M. Herjayanto, . 2019b. The utilization of vegetable waste silage as feed ingredient in diets for tilapia, Oreochromis niloticus. Proceeding, The $1^{\text {st }}$ International Conference on Agriculture and Rural Development (ICARD). Serang, 8-9 August 2019. IOP Conference Series: Earth and Environmental Science, Volume 383.

Putra, A.N., W.N. Ningsih, F.S. Nurani, Mustahal \& F.R. Indariyanto. 2018. Evaluasi fermentasi daun kelor (Moringa oleifera) sebagai bahan baku pakan ikan nila (Oreochromis niloticus). Jurnal Perikanan dan Kelautan 8 (2): 104-113.

Putra, A.N., A.C. Pradana, D. Novriansyah \& Mustahal. 2019a. Effect of dietary fermented lamtoro (Leucaena leucocephala) leaves flour in feed on digestibility and hematological parameter of catfish (Clarias sp.) Jurnal Rekayasa dan teknologi budidaya perairan VIII (1): 951-963.

Samkelisiwe, N.H. \& A.G.M. Ngonidzashe. 2014. Replacing fishmeal with kikuyu grass and moringa leaves: Effects on growth, protein digestibility, histological and haematological parameters in Clarias gariepinus. Turkish Journal of Fisheries and Aquatic Sciences 14: 795-806.

Setyoko, H \& B. Utami. 2016. Isolasi dan karakterisasi enzim selulase cairan rumen sapi untuk hidrolisis biomassa. Prosiding Seminar Nasional XIII Pendidikan Biologi. Surakarta, 6 Oktober 2016. Universitas Sebelas Maret, 13 (1): 863-867.

Shahzad, M.M., S.M. Hussain, A. Javid \& M. Hussain. 2018. Role of phytase supplementation in improving growth parameters and mineral digestibility of Catla catla fingerlings fed moringa by-products based test diet. Turkish Journal of Fisheries and Aquatic Sciences 18: 557-566. 
Slawski, H., F. Nagel, K. Wysujack, D.T. Balke, P. Franz \& Schulz. 2013. Total fish meall replacement with canola protein isolate in diets fed to rainbow trout (Oncorhynchus mykiss W.). Aquaculture Nutrition 19 (4): 535-542.

Suprayudi, M.A., S. Alim, I.A. Fauzi, J. Ekasari, M. Setiawati, M.Z. Junior \& A.G. Tacon. 2017. Evaluation of hydrolysed rubber seed meal as a dietary protein source for nile tilapia Oreochromis niloticus L. Aquaculture Research 48 (7): 3801-3808.

Suprayudi, M.A., W. Dimahesa, D. Jusadi, M. Setiawati \& J. Ekasari. 2011. Suplementasi crude enzim cairan rumen domba pada pakan berbasis nabati dalam memacu pertumbuhan ikan nila (Oreochromis niloticus). Jurnal Iktiologi Indonesia 11 (2): 177-183.

Suprayudi, M.A., W.S. Irawan \& N.B.P. Utomo. 2014. Evaluasi tepung bungkil biji karet difermentasi cairan rumen domba pada pakan ikan patin. Jurnal Akuakultur Indonesia 13 (2): 146-151.

Takeuchi, T. 1988. Laboratory work-chemical evaluation of dietary nutrients. In: Watanabe, editor. Fish Nutrition and Mariculture. Kanagawa International Fisheries Training. Japan International Cooperation Agency (JICA), Japan. pp.179-233.

Tan, Q., D. Song, X. Chen, S. Xie \& X. Shu. 2018. Replacing fish meal with vegetable protein sources in feed for juvenile red swamp crayfish, Procambarus clarkia: Effects of amino acids supplementation on growth and feed utilization. Aquaculture Nutrition 24 (2): 858-864.
Watanabe, T. 1988. Fish nutrition and mariculture. Departement of Aquatic Bioscience. Tokyo University of Fisheries. JICA, p.79-82.

Weiss, M., A. Rebelein \& M.J. Slater. 2020. Lupin Kernel Meal as Fishmeal Replacement in Formulated Feeds for the Whiteleg Shrimp (Litopenaeus vannamei). Aquaculture Nutrition 26 (3): 752-762.

Williams, A.G. \& S.E. Withers. 1992. Changes in the rumen microbial population and its activities during the refaunation period after the reintroduction of ciliate protozoa into the rumen of defunated sheep. Canadian J. Microbiology 39: 61-69.

Yusuf, D., M.A. Suprayudi \& D. Jusadi. 2016. Peningkatan kualitas pakan ikan nila berbahan tepung bungki biji karet melalui suplementasi asam amino. Jurnal Akuakultur Indonesia 15 (1): 63-69.

Zhang, C., S. Rahimmejad, Y-R. Wang, K. Lu, K. Song, L. Wang \& K. Mai. 2018. Substituting fish meal with soybean meal in diets for Japanese seabass (Lateolabrax japonicas): Effects on growth, digestive enzymes activity, gut histology, and expression of gut inflammatory and transported genes. Aquaculture 483: $172-182$.

Zuraida, D. Jusadi \& N.B.P. Utomo. 2012. Efektivitas penggunaan enzim cairan rumen domba terhadap penurunan serat kasar dan peningkatan kecernaan bungkil kelapa sebagai pakan ikan nila merah Oreochromis sp. Jurnal Akuakultur Rawa Indonesia 1 (2): 117-126. 